\title{
Engineering Students' Innovation Competence: A Comparative Analysis of Nigeria and South Africa
}

\author{
https://doi.org/10.3991/ijep.v10i6.14695 \\ Omoseni Adepoju ${ }^{(凶)}$, Nnamdi Nwulu \\ University of Johannesburg, Johannesburg, South Africa \\ adepojuomoseni@gmail.com
}

\begin{abstract}
The main purpose of this study is to assess the role of tertiary institutions in impacting innovation competence among graduating students in the engineering discipline. To achieve this aim, two research questions were investigated: First, we examine if the graduating students possess some key innovative competence qualities innovative competence which include qualities such as creativity, leadership, self-efficacy, energy and risk propensity. Secondly, we investigate the key elements of tertiary institutions that impact innovative competence among the graduating students. A structured questionnaire was administered to graduating engineering students at the Federal University of Technology Akure, Nigeria and University of Johannesburg, South Africa during the 2019/2020 academic session and their responses were compared. Results indicate that students generally had a high assessment of their innovation competence and attributed some of this competence to their institutions learning environment.
\end{abstract}

Keywords-Innovation, Competence, Tertiary institutions, Engineering

\section{Introduction}

Innovation competence can be defined as the ability to conceptualize and execute ingenious ideas that have practical and tangible impact [1]. These ingenious ideas can either take the form of a product or service [1]. There is an attitude and skill set required to successfully conceptualize and implement innovative ideas consisting of precise knowledge, resilience, self-motivation and creativity [2]. This is because innovation is a complex endeavor and the innovation process involves uncertainty with no guarantee of success [13].

Of crucial importance from an engineering pedagogy perspective is the learning environment where innovation competence is nurtured. It is imperative that learning environments are deliberately designed to foster this competence.

A good way to gauge the effectiveness of learning environments in fostering innovation competence is to evaluate students' perceptions of their learning environments. Prior research has shown that there is direct correlation between students' perception of their learning environment, learning outcomes and innovation competence [4]. If the aim is to design pedagogically sound approaches that foster innovation competence in the engineering context, teachers have to obtain feedback via students' self-assessment 
of their own innovation competence. Furthermore, it is also imperative to obtain students assessments of their learning environment and if it fosters innovation competence. There has thus been a commensurate interest in understanding how the learning environment contributes to developing innovation competence [3] from the literature. A recent work that investigates these concepts is [5] where students' assessment of their own competence and their learning environment was performed. This was done via the distribution of 130 questionnaires to build environment students seeking to measure their opinion on whether their institution's curricula had succeeded in fostering innovation competence. This work builds on the approach adopted in [5] and performs a comparative analysis of students' self-assessment of their innovation competence and that of their learning environments in Nigeria and South Africa. The choice of Nigeria and South Africa is motivated by the fact that both nations account for approximately $50 \%$ of sub-Saharan Africa's gross domestic product [6] and South Africa is regarded as the most innovative country on the African continent [7].

The main purpose of this study is therefore to assess the role of tertiary institutions in impacting innovative skills among graduating students in the Engineering field, using both Nigeria and South Africa as a case study. The specific objectives are to:

a) Examine engineering graduating students' self-assessments of their innovative competence

b) Investigate the key elements of tertiary institutions learning environments that impart innovative competence among the graduating students.

The rest of this paper comprises of the conceptual framework for innovation competence and innovation learning environments, research methodology, results and discussions of findings respectively. In addition, the paper was concluded in line with findings and recommendations were made.

\section{Conceptual Framework}

Within the engineering education domain, the framework for assessing innovation competence amongst tertiary institutions utilizes six key components [2], [5]. The first key component is Creativity. Creativity is the first attribute required after the identification of a complex problem [2], [8]. The creative problem solver (in this case a student) has to keep an open mind about the vast possibilities of variables and/or parameters that affect the problem and possible solutions. Furthermore, the creative problem solver has to be able to draw connections and causal relationships between various scenarios in the problem domain [10],[11]. Creativity involves questioning assumptions, challenging stereotypes and leveraging on the power of imagination [8]. The second component of innovation competence is leadership. Leadership is the ability to obtain the wholehearted buy in of all partners and team members in order to actualize the envisaged solution to the problem at hand [2]. The third component of innovation competence is referred to as creative self-efficacy, which simply put is the degree of self-confidence a student has in their problem-solving ability. This component is linked to the domain specific knowledge the student has. The fourth component is termed energy, which refers to the ability to doggedly pursue an innovative solution to hitherto identified 
problems [2]. This component is key as it describes the ability to surmount challenges/obstacles on the path to obtaining solutions. The fifth component is risk propensity. Risk propensity is one of the key traits of innovators as they are able to ignore the uncertainty within the problem domain and find solutions. The sixth component is termed ambiguous problem solving and relates to the ability of students to persevere and find solutions to ill-defined or ambiguous problems. The authors believe that elements of this component have been captured in the prior five components and thus will be excluded in this paper. These are also the components detailed in [2].

Concerning learning environments, prior research has shown that teachers have long sought to foster and/or develop students' innovation competence through teaching [5]. The learning environment under which teaching is done therefore deserves scrutiny. We therefore investigate the effect of five learning environment factors on the innovation competence of students. The five factors are lecturers' teaching method, modernized learning techniques, institutional infrastructural capacity, university-industry collaboration and the level of institutional funding. The choice of the learning environment factors is motivated by the analysis of relevant literature [13] which posit that these are key learning environment factors. The hypothesis constructed and investigated in light of the five factors are:

Hypothesis 1: The lecturers' teaching method significantly impacted the acquisition of innovative competence among the graduating students in Engineering.

Hypothesis 2: Modernized learning techniques significantly impacted the acquisition of innovative competence among graduating students in Engineering.

Hypothesis 3: Institutional infrastructural capacity significantly impacted the acquisition of innovative competence among graduating students in Engineering.

Hypothesis 4: University - Industry Collaboration in the institution significantly impacted the acquisition of innovative competence among graduating students in Engineering.

Hypothesis 5: Level of research funding in the institution significantly influenced the acquisition of innovation competence among graduating students.

\section{Methods}

The population of the study comprised of final year engineering students at the University of Johannesburg (UJ) in South Africa and Federal University of Technology (FUTA) in Nigeria. A total number of $530(\mathrm{UJ}=210+$ FUTA $=293)$ were derived from the 2019/2020 academic session. The sample size (n) was calculated using Taro Yamane formula [12].

$$
\mathrm{n}=\mathrm{N}
$$

where $\mathrm{n}=$ sample size, $\mathrm{N}=$ population size, and $\mathrm{e}=$ Margin of error $(\mathrm{MoE}), \mathrm{e}=0.05$.

This calculation gives a sample of 138 (UJ) and 169 (FUTA). A structure questionnaire was used to collect data. The questionnaires were crafted in line with the research objectives of the study. i.e. to obtain students assessment of their own innovation competence and secondly to investigate the key elements of tertiary institutions learning environments that impact innovative competence among graduating students. This methodology was adopted in line with prior related works on the subject matter [2], [5]. 
A five-point Likert response scale was used with responses Strongly Disagree, Disagree, Undecided, Agree and Strongly Agree for questions that correspond to the five components of innovation competence. In order to answer research objective 1, the obtained student responses were analysed using calculated mean and standard deviation values. For research objective two, simple liner regression was performed which sought to find out what factors in the institutions learning environment influenced student's innovation competence.

\section{Questionnaire Response Rate}

Out of 138 questionnaires distributed to UJ, 90 were retrieved and out of 169 distributed to FUTA, 105 were retrieved. This gives a response rate of $65 \%$ and $62 \%$ for UJ and FUTA respectively. This response rate was considered adequate and consistent with [9] who suggests that any response rate above $50 \%$ is generally representative for a descriptive study. Therefore, the sample was considered adequate for the researcher to draw a conclusion and generalize research findings. The demographic characteristics of the respondents is given in Table 1 .

Table 1. Demographic Characteristics of the Students

\begin{tabular}{|l|c|c|c|c|}
\hline & \multicolumn{2}{|c|}{ UJ } & \multicolumn{2}{c|}{ FUTA } \\
\hline & Frequency & Percentage (\%) & Frequency & Percentage (\%) \\
\hline Gender & & & & \\
\hline Male & 73 & 81.1 & 90 & 85.7 \\
\hline Female & 17 & 18.9 & 15 & 14.7 \\
\hline Total & 90 & 100 & 105 & 100 \\
\hline Age & & & & \\
\hline Below 15 & & & & \\
\hline $16-20$ & 17 & 18.9 & 21 & 20.0 \\
\hline $21-25$ & 54 & 60.0 & 66 & 62.9 \\
\hline $26-30$ & 19 & 21.1 & 18 & 17.1 \\
\hline above 30 & - & - & - & - \\
\hline Total & 90 & 100 & 105 & 100 \\
\hline Educational Background & & & & 100 \\
\hline Engineering & 90 & 100 & 105 & 100 \\
\hline Total & 90 & 100 & 105 & FUTA \\
\hline Institution & & UJ & & \\
\hline
\end{tabular}

Source: Research Data (2019)

\section{$4 \quad$ Results}

Results obtained for research objective 1 are shown in Table 2 and Figure 1 respectively. Table 2 gives the mean scores of UJ and FUTA students' innovation self-assessments corresponding to the five innovation competence components. Figure 1 shows the overall mean for each of the five components for students of both institutions. 
Table 2. Assessment of Level of Innovative Skills among graduating students in UJ and FUTA

\begin{tabular}{|c|c|c|}
\hline \multirow[b]{2}{*}{ Creativity } & \multicolumn{2}{|c|}{ Mean } \\
\hline & UJ & FUTA \\
\hline My courses involved lot of creative activities & 4.18 & 3.632 \\
\hline My course of study has facilitated my power of imagination & 3.91 & 3.662 \\
\hline $\begin{array}{l}\text { My course of study has driven me to generate ideas and solutions to problems relating to } \\
\text { my field }\end{array}$ & 4.26 & 3.809 \\
\hline My course involved real life practical's in school which aided my creative thinking & 4.24 & 3.824 \\
\hline I have learnt how to make complex choices and decisions in the course of my study & 4.38 & 3.559 \\
\hline $\begin{array}{l}\text { I have learnt to be inquisitive and ask questions to clarify various doubts and broaden my } \\
\text { knowledge in the course of my study }\end{array}$ & 4.24 & 3.809 \\
\hline $\begin{array}{l}\text { My course involved real life practical's in school which aided my creative thinking } \\
\text { (from the environment) }\end{array}$ & 4.29 & 3.882 \\
\hline \multicolumn{3}{|l|}{ LEADERSHIP } \\
\hline Students are encouraged to take leadership roles during my study & 3.97 & 4.029 \\
\hline $\begin{array}{l}\text { Distribution into class groups gives me a chance to take a leading role (in form of team/ } \\
\text { group leader) }\end{array}$ & 3.71 & 4.103 \\
\hline $\begin{array}{l}\text { My course entails series of seminars and presentations which have improved my commu- } \\
\text { nication skills with lecturers and colleagues }\end{array}$ & 3.68 & 3.206 \\
\hline $\begin{array}{l}\text { My course avails me the opportunity to inspire my colleagues through sharing } \\
\text { knowledge and tutorials }\end{array}$ & 4.03 & 3.632 \\
\hline $\begin{array}{l}\text { My course gave me the freedom to take decisions independently to generate results/ so- } \\
\text { lutions }\end{array}$ & 3.97 & 3.765 \\
\hline \multicolumn{3}{|l|}{ ENERGY } \\
\hline In my course, excellence is rewarded based on hard work & 4.18 & 3.265 \\
\hline My courses demand much energy to get results & 4.26 & 3.941 \\
\hline I have learnt to exert energy to get good grades in my courses & 4.29 & 3.912 \\
\hline I spent long hours and effort to come up with innovation & 4.38 & 3.956 \\
\hline My course has built up energy required to get to the peak in my profession & 4.03 & 3.691 \\
\hline \multicolumn{3}{|l|}{ SELF- EFFICACY } \\
\hline I work independently to generate results in the course of my study & 4.00 & 3.588 \\
\hline I have designed something in the course of my study and I feel proud about it & 4.21 & 2.956 \\
\hline My course gave me freedom to express my own ideas & 4.09 & 3.912 \\
\hline Due to my course of study, I have developed self-confidence over the years & 4.06 & 3.721 \\
\hline I am not afraid to face any challenge in my pursuit of my profession & 4.15 & 3.779 \\
\hline The school have brought me up to always think for myself & 3.82 & 3.588 \\
\hline \multicolumn{3}{|l|}{ RISK PROPENSITY } \\
\hline My course involves a high level of risk taking & 4.03 & 3.632 \\
\hline $\begin{array}{l}\text { My course has increased my risk taking and my ability to come up with solutions to } \\
\text { problems }\end{array}$ & 4.44 & 3.309 \\
\hline $\begin{array}{l}\text { My Experience in my course of study has given me the confidence that I can solve any } \\
\text { problem }\end{array}$ & 4.00 & 3.368 \\
\hline I take decisions based on my drive to achieve regardless of future consequences & 3.74 & 3.574 \\
\hline $\begin{array}{l}\text { I take risks on an activity that might enhance my chances of getting good grades in } \\
\text { school. }\end{array}$ & 4.15 & 3.926 \\
\hline
\end{tabular}




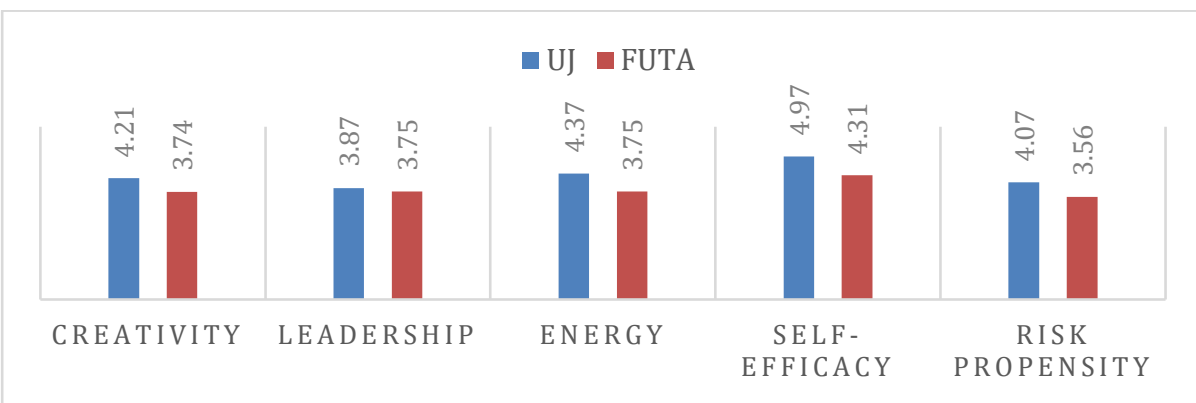

Fig. 1. Assessment of Level of Innovative Skills among graduating students in UJ and FUTA

Table 3 below shows a simple regression analysis of the impact of five learning environment factors on the innovation competence of students. The five factors are lecturers' teaching method, modernized learning techniques, institutions infrastructural capacity, university-industrial collaboration and the level of institutions funding corresponding to five hypotheses. Results in Table 4 show the following metrics: $\mathrm{R}, \mathrm{R}^{2}, \mathrm{~F}-$ ratio and the significance ( $\mathrm{P}$ value).

Table 3. Key elements of tertiary institutions learning environments that impact innovative competence among graduating students

\begin{tabular}{|l|c|c|c|c|c|c|c|c|c|c|}
\hline & \multicolumn{2}{|c|}{ HO1 } & \multicolumn{2}{c|}{ HO2 } & \multicolumn{2}{c|}{ HO3 } & \multicolumn{2}{c|}{ HO4 } & \multicolumn{2}{c|}{ HO5 } \\
\hline & $\boldsymbol{U J}$ & $\boldsymbol{F U T A}$ & $\boldsymbol{U J}$ & $\boldsymbol{F U T A}$ & $\boldsymbol{U}$ & $\boldsymbol{F U T A}$ & $\boldsymbol{U}$ & $\boldsymbol{F U T A}$ & $\boldsymbol{U}$ & $\boldsymbol{F U T A}$ \\
\hline $\mathrm{R}$ & 0.625 & 0.701 & 0.858 & 0.901 & 0.701 & 0.858 & 0.869 & 0.855 & 0.865 & 0.990 \\
\hline $\mathrm{R}^{2}$ & 0.390 & 0.492 & 0.737 & 0.811 & 0.492 & 0.737 & 0.755 & 0.731 & 0.732 & 0.979 \\
\hline $\mathrm{F} /$ ratio & 74.2 & 69.2 & 34.2 & 24.3 & 53.63 & 34.25 & 30.33 & 14.13 & 12.66 & 40.79 \\
\hline $\mathrm{P}$ & 0.005 & 0.15 & 0.002 & 0.653 & 0.148 & 0.002 & 0.004 & 0.163 & 0.210 & 0.00 \\
\hline
\end{tabular}

\section{Discussion}

Research Objective 1: Self-assessment of innovative competence among graduating students in UJ and FUTA

In Table 3 a comparative assessment of the level of innovation skills which was distilled into 5- stages- creativity, leadership, energy, self -efficacy and risk propensity was conducted among the students of UJ and FUTA. The results show that UJ students assess themselves as having higher levels of innovation competence than FUTA students have. UJ students typically scored themselves high on creativity, self-efficacy and energy. They scored themselves much lower on leadership and risk propensity. FUTA students on the other hand rated self-efficacy as their most innovative trait with risk propensity their lowest rated trait. Creativity, energy and leadership were rated almost equally. The results obtained from UJ students aligns with what is obtainable in the literature [2], [5] where students scored themselves highly on creativity, self-efficacy and energy. It was postulated in these works that students who score high scores in these components are in line to be innovators outside the University. This perhaps explains why South Africa is the most innovative country on the African continent. 
However, the UJ results are an indication that students need to take the initiative in problem solving and risk taking. Deliberate steps have to be taken where students take the initiative in solving problems whilst doing so out of their comfort zones. This can be via increased incorporation of Project Based Learning (PBL) subjects/modules into the UJ curricula, as this will increase the students' problem-solving capacity. FUTA students assessed themselves highly for self-efficacy, which suggests a heathy dose of problem-solving confidence. However, in light of the lower creativity, energy and leadership scores, it is advised that courses be designed with creative and practical activities, which will enhance the students' power of imagination and creative ability. Students should also be encouraged to take the driving seat in innovative activities. A key method to achieve this should be the increased inclusion of ill-defined problem solving in the FUTA curricula, as the lack of clear-cut solution methodology (a key tenet of ill-defined problem solving) will foster students' creative capacity.

Research Objective 2: Investigate the key elements of tertiary institutions learning environments that impact innovative competence among graduating students.

In order to investigate this research objective, five hypotheses were constructed and the responses of the students sought. From Table 4 hypothesis 1, UJ students record a significance level $(\mathrm{p}=0.005)$ which indicates that the model is significant at $\mathrm{p}<0.005$. This implies that in the opinion of the students, lecturers' teaching method significantly influence the acquisition of innovative competence. Analysis of FUTA student's response on the other hand yielded a significance level $(\mathrm{p}=0.15)$ which indicates that the lecturers' teaching method does not significantly influence the acquisition of innovative competence. Similar analysis shows that UJ students posit that modern teaching methods and university-industry collaboration also impact influence their acquisition of innovation competence. UJ students posit that the level of institutional funding and infrastructural capacity do not influence their learning environment for innovative competence whilst these are the factors that FUTA students posit influence theirs. This can be explained by the fact that UJ has better infrastructural capacity and funding that FUTA and UJ students probably accept it as a given. FUTA students on the other hand believe that it has a significant effect on their learning experience and subsequently on their innovative competence.

\section{Conclusion}

This article considered the self-assessment of engineering students' innovation competence and the effect learning environments of tertiary institutions had on this competence. Final year engineering students at the University of Johannesburg and the Federal University of Technology Akure in South Africa and Nigeria respectively were the study respondents. UJ students typically scored themselves high on creativity, self-efficacy and energy. They scored themselves much lower on leadership and risk propensity. FUTA students on the other hand rated self-efficacy as their most innovative trait with risk propensity their lowest rated trait. Creativity, energy and leadership were rated almost equally. The students also identified the learning environment attributes in their institutions that fostered their innovative competence. The results indicate that there is 
still need for deliberate attempts to increase the innovative capacity of students in UJ and FUTA. A key recommendation is that more PBL and ill-defined problem solving should be introduced into the engineering curricula at UJ and FUTA respectively. Future research work should assess innovation competence using a larger sample size, across various disciplines and various education levels.

\section{$7 \quad$ References}

[1] J. Tidd and J. Bessant, Managing innovation, 6th ed. Wiley, 2018

[2] E. Chell and R. Athayde, The identification and measurement of innovative characteristics of young people, London, NESTA, 2009.

[3] R. Beghetto and J. Kaufman, "Classroom contexts for creativity", High Ability Studies, vol. 25, no. 1, pp. 53-69, 2014. https://doi.org/10.1080/13598139.2014.905247

[4] S. Chan and M. Yuen, "Personal and environmental factors affecting teachers' creativity-fostering practices in Hong Kong", Thinking Skills and Creativity, vol. 12, pp. 69-77, 2014. https://doi. org/10.1016/j.tsc.2014.02.003

[5] A. Ovbiagbonhia, B. Kollöffel and P. Brok, "Educating for innovation: students' perceptions of the learning environment and of their own innovation competence", Learning Environments Research, vol. 22, no. 3, pp. 387-407, 2019. https://doi.org/10.1007/s10984-019-09280-3

[6] "South Africa no longer has the biggest economy in Africa", Businesstech.co.za, 2020. [Online]. Available: https://businesstech.co.za/news/business/378841/south-africa-no-longer-has-the-biggest-economy-in-africa/. [Accessed: 07- Feb- 2020].

[7] "Global Innovation Index 2019", Wipo.int, 2020. [Online]. Available: https://www.wipo.int/ global_innovation_index/en/2019/. [Accessed: 07- Feb- 2020].

[8] A. Antonietti, "The WCR Model of Creativity. From Concept to Application", The Open Education Journal, vol. 4, no. 1, pp. 80-89, 2011.

[9] O. M. Mugenda and A. G. Mugenda, Research methods: Quantitative and qualitative Approaches. Nairobi: African Centre for Technology Studies, 2003.

[10] I. Atoum, "A Spiral Software Engineering Model to Inspire Innovation and Creativity of University Students", International Journal of Engineering Pedagogy (iJEP), vol. 9, no. 5, pp. 7, 2019. https://doi.org/10.3991/ijep.v9i5.10993

[11] N. Songkram, "Online Course Design for Creativity and Innovative Skills in Virtual Cultural ASEAN Community: From Research to Empirical Practice", International Journal of Emerging Technologies in Learning (iJET), vol. 12, no. 01, pp. 4, 2017. https://doi.org/10.3991/ijet. v12i01.6032

[12] P. Somboonsak, "Development Innovation to Predict Dengue Affected Area and Alert People with Smartphones", International Journal of Online and Biomedical Engineering (iJOE), vol. 16, no. 02, pp. 62, 2020. https://doi.org/10.3991/ijoe.v16i02.12425

[13] P. Poutanen, W. Soliman and P. Ståhle, "The complexity of innovation: an assessment and review of the complexity perspective", European Journal of Innovation Management, vol. 19, no. 2, pp. 189-213, 2016. https://doi.org/10.1108/ejim-03-2014-0036 


\section{Authors}

Omoseni Adepoju is a Post-Doctoral Research Fellow, Faculty of Engineering and Built Environment, University of Johannesburg, RSA. Email: adepojuomoseni@ gmail.com

Nnamdi Nwulu is an Associate Professor, Faculty of Engineering and Built Environment, University of Johannesburg, RSA.

Article submitted 2020-04-07. Resubmitted 2020-05-28. Final acceptance 2020-05-28. Final version published as submitted by the authors. 




iJEP - Vol. 10, No 6, 2020

Imprint

iJEP - International Journal of Engineering Pedagogy

Online issue: http://www.i-jep.org

Editor-in-Chief

Matthias Christoph Utesch, TU München, Germany

Executive Editor

Michael E. Auer, CTIVillach, Austria

Deputy Editor-in-Chief

Matthias Gottlieb, TU München, Germany

Senior Editor

Klaus-Tycho Foerster, University of Vienna, Austria

Editors

José Couto Marques, University of Porto, Portugal

Tatiana Yurievna Polyakova, MADI, Moscow, Russian Federation

Istvan Simonics, Obuda University, Hungary

\section{Technical Editor}

Sebastian Schreiter, Lagorce, France

\section{Editorial Board}

Teresa L Larkin, American University, United States

Eleonore Lickl, HBLVA, Vienna, Austria

Maria Teresa Restivo, University of Porto, Portugal

Tiia Rüütmann, Tallinn University of Technology, Estonia

Phillip A. Sanger, Purdue University College of Technology, United States

Alexander Solovyev, MADI, Moscow, Russian Federation

James Wolfer, Indiana University South Bend, United States

Axel Zafoschnig

\section{Indexing}

International Journal of Engineering Pedagogy (iJEP) is indexed

in Elsevier Scopus, Clarivate Analytics ESCI, EBSCO, DOAJ and DBLP.

\section{Publication Frequency}

Bi-monthly (January, March, May, July, September, November)

\section{ISSN}

2192-4880

\section{Publisher}

International Society of Engineering Education (IGIP)

Europastrasse 4

A-9524 Villach

Austria 